\title{
THE ROLE OF THE CENTRAL BANK IN FOREIGN EXCHANGE INSPECTION IN SELECTED COUNTRIES OF THE EUROPEAN UNION - AS SEEN IN THE EXAMPLE OF POLAND, THE CZECH REPUBLIC AND GERMANY
}

\author{
Ewa Kowalewska*
}

\begin{abstract}
The activity of central banks in EU states is based on similar assumptions. Their aim is usually to maintain a stable level of prices and to support the state's economic policy. Central banks are responsible for issuing money and for monetary policy. They have been equipped with adequate instruments to this end. The aim of this research is to demonstrate that legislation in Poland, the Czech Republic and Germany vested another important function in the central banks, namely foreign exchange inspection. However, this function is exercised differently in each of them. The central banks of countries referred to above are not only responsible for currency in circulation within the country but also for the balance of payments. Also, by pursuing their own foreign exchange policy they ensure an adequate position of the national currency in relation to foreign ones. The foreign exchange inspection in each of these countries is based on a different tradition and at the same time outlines the special role of the central bank. The analysis herein makes it possible to establish the scope of this inspection, taking into account the dynamics of changes that occur on the legal ground. What is also important here is whether a given country is only a member of the European Union or a member of the EU and of the euro area. The adopted research methodology is based on analysis of legislation in force with a reference to views expressed by legal commentators.
\end{abstract}

Keywords: central bank, foreign exchange inspection, supervision

* Dr. Ewa Kowalewska, Assistant Professor, Faculty of Law and Administration, University of Szczecin; correspondence address: ul. Narutowicza 17a, 70-240 Szczecin, Poland; e-mail: ewa.kowalewska@usz.edu.pl; https://orcid.org/0000-0001-8167-6579. 


\section{INTRODUCTION}

The history of central banking in Europe dates back to the turn of the seventieth and eighteenth century and the Bank of England can be treated as its prototype. In the ninetieth century issuing banks were established in a number of other countries and in the twentieth century they became universally functioning institutions ${ }^{1}$.

In the majority of contemporary countries, the central bank functions as an independent institution. Taking into account the comparative aspect one needs to point to two categories of central banks in European Union (EU) states. These are central banks of countries which belong to the Euro zone and central banks of countries outside the euro area. Given the above, the role and position of the central banks of Poland, Germany and the Czech Republic as examples of central banking functioning on different economic, political and social terms will be presented in further parts of this discussion. The central banks of these countries will be presented principally in terms of their responsibility for foreign exchange inspection.

Each central bank is tasked with a broadly understood monetary policy. On the basis of regulations legally binding in EU countries one may notice that in each of them the central bank has a special place, both in the economic and social system. This specific nature of the central bank results primarily from its monopoly in creating money ${ }^{2}$. Nevertheless, it is not its only capacity. Next to the issuing function, the central bank also has the function of the central bank of the State and of the banks' bank. At the same time, it needs to be stressed that central banks in some EU countries also play another, special function of the so-called

1 Hans Aufricht, Comparative Survey of Central Bank Law (New York, Washington: Frederick A. Praeger, 1965), 7; Hanna Gronkiewicz - Waltz, Bank centralny od gospodarki planowej do rynkowej (Warsaw: Wydawnictwo Prawnicze, 1992), 18; Paweł Baltyn, "Modelowe ujęcie polityki monetarnej w warunkach kryzysu," in Wspótczesny system bankowy. Ujęcie interdyscyplinarne, ed. Joanna Świderska (Warsaw: Difin, 2013), 264, 264.

2 Stanisław Owsiak, "Bank centralny," in Bankowośc, ed. Małgorzata Zaleska (Warsaw: C.H. Beck, 2013), 13. 
central banking foreign exchange institution tasked with foreign exchange inspection.

\section{SCOPE OF RESEARCH AND METHODOLOGY}

The subject of the described research involves legal instruments relevant to the functioning of central banks in selected EU states, mainly in terms of responsibilities under foreign exchange inspection. Regulations in force in Poland, Germany and the Czech Republic relating to the central bank and foreign exchange inspection feature a different degree of detail. The aim of the analysis is to show the differences and/or similarities in setting standards in the discussed scope. A hypothesis may be put forward against this background that there is no uniform regulation in the area of foreign exchange inspection at the EU level.

The research method adopted by the author was based on the analysis of legislative acts key to the issue in question with reference to selected views expressed in the literature. Given the above, it must be concluded that the main research method involved legal comparison and an analysis of binding law.

The discussed subject-matter concerns the sphere of the functioning of the central bank where even though the principles of operation of central banking are standardized, certain differences may be noticed in the area of foreign exchange inspection. Europeanization in the sphere of central banking should aim to single out universal principles and standards, including central banks' responsibilities relating to the discussed scope. It is especially important due to the principle of freedom of foreign exchange, which shapes inter alia the economic development of EU states, and also due to the central bank's responsibility for security and stability on the financial market.

\section{CENTRAL BANKING AND FOREIGN EXCHANGE INSPECTION IN POLAND}

Poland's Narodowy Bank Polski (NBP), as the central bank, takes a special position in the national banking system in Poland. This position 
involves three elements: objectives, scope of functions and responsibilities, and legal status ${ }^{3}$. NBP's main objective is to maintain a stable level of prices. Secondly, it is tasked with supporting the government's economic policy. NBP as a legal person acts through its organs. Pursuant to the Constitution of the Republic of Poland ${ }^{4}$ these organs are: the President of the NBP, the Council for Monetary Policy and the Board of the NBP.

In terms of foreign exchange inspection, which is the subject of this research, the President of the NBP holds special powers which are primarily regulated by the Act on the National Bank of Poland ${ }^{5}$ and the Foreign Exchange Law ${ }^{6}$.

NBP as the central bank performs a number of actions that fit within its functions: the banks' bank, the central bank of the State and the issuing bank. Along with the responsibilities enumerated above, the NBP also holds the function of the central banking foreign exchange institution $^{7}$. It is an organ with a special legal status in terms of foreign exchange which entails the capability of stipulating foreign exchange restrictions ${ }^{8}$. The Act on the NBP includes a catalogue of tasks carried out by the NBP as the central banking foreign exchange institution. These include inter alia foreign exchange reserve management, undertaking banking activities aimed at ensuring the security of foreign exchange and the state's payment liquidity. The NBP may act as the government's financial agent in terms of conclusion and implementation of credit agreements and han-

3 Rafał Mroczkowski, "Status prawny, cele, funkcje i zadania Narodowego Banku Polskiego," in Podstawy finansów i prawa finansowego, ed. Andrzej Drwiłło (Warsaw: Wolters Kluwer, 2018), 351.

4 The Constitution of the Republic of Poland, Journal of Laws 1997, No. 78, item 483, as amended, section 227.

5 Act on the National Bank of Poland of August 29, 1997, consolidated text, Journal of Laws 2019 item 1810.

6 Foreign Exchange Law of July 27, 2002, consolidated text, Journal of Laws 2019 item 160.

7 Krzysztof Oplustil and Marek Porzycki, "Unia walutowa w Europie," in Instytucje gospodarki rynkowej, eds. Tadeusz Włudyka and Marcin Smaga (Warsaw: Wolters Kluwer, 2018), 286, 293.

8 Ewa Kowalewska, "Narodowy Bank Polski jako centralna bankowa instytucja dewizowa," Finanse, Rynki Finansowe, Ubezpieczenia, no. 79 (2016): 682. 
dling external debt. Moreover, the NBP's responsibilities in this scope also include performing inspections within limits established by the provisions of the Foreign Exchange Law.

The Foreign Exchange Law regulates foreign exchange in the manner required by the EU principle of the free movement of capital and external payments? . In Poland the model of foreign exchange law has run through a long path of changes that have led to liberalization. The changes that have occurred in legislation in force resulted primarily from adjusting Polish foreign exchange law to community's norms and principles guaranteed under EU law ${ }^{10}$. Foreign exchange legislation has been transformed from being restrictive to a law which supports economic processes ${ }^{11}$.

Foreign exchange inspection, as the responsibility of the President of the NBP, concerns the following three areas:

a) individual foreign exchange licenses granted,

b) activity of currency exchange offices,

c) statistical reporting in terms of providing information for the state's balance of payments and international investment position.

The relevant powers of the President of the NBP include other responsibilities regulated under the Foreign Exchange Law. These are mainly: maintaining the register of operators of currency exchange offices and issuing individual foreign exchange licenses. The President of the NBP makes an entry in the register of currency exchange offices on the basis of a written application submitted by the operator. Currency exchange operation can be carried out in compliance with the Entrepreneurs Act ${ }^{12}$. Entry in

9 Eugenia Fojcik-Mastalska, "Miejsce i rola prawa walutowo - dewizowego w systemie prawa," in Prawo finansowe w warunkach cztonkostwa Polski w Unii Europejskiej. Ksiega Jubileuszowa dedykowana Profesor Wandzie Wójtowicz, eds. Alicja Pomorska, Paweł Smoleń and Jarzy Stelmasiak (Lublin: Wydawnictwo Uniwersytetu Mari Curie-Skłodowskiej, 2011), 99, 107.

10 Ewa Kowalewska, "Ustawodawstwo dewizowe w systemie prawa - analiza z perspektywy członkostwa Polski w Unii Europejskiej," in Obywatel - Państwo - Spoteczność Międzynarodowa, eds. Ewelina Cała - Wacinkiewicz, Kinga Flaga - Gieruszyńska and Daniel Wacinkiewicz (Warsaw: C.H. Beck, 2014), 570, 584.

11 Kowalewska, "Narodowy Bank Polski," 680.

12 Entrepreneurs Act of March 6, 2018, consolidated text Journal of Laws 2019 item 1292 as amended. 
the above register is made in the form of an administrative decision, where removal from the register is also an entry, which causes specific consequences in the event of filing an appeal against such a decision. An entrepreneur carrying out currency exchange operations has been given a number of responsibilities, which were mainly specified in the Regulation of the Minister of Finance ${ }^{13}$ on equipping premises dedicated to carrying out currency exchange operations and the manner of record keeping and issuing evidence of purchase and sale of foreign exchange. It needs to be noted that foreign exchange inspection of currency exchange activity includes also the operator's observance of obligations imposed on him by the Act on Preventing Money Laundering and Financing of Terrorism ${ }^{14}$. It needs to be highlighted that it is a broadly developed direction of inspection due to the changing relevant regulations. Moreover, it is worth stressing that prevention of money-laundering has recently gained a transnational dimension and each of the analyzed countries pays particular attention to this issue, which results mainly from the analyzed legislation.

Currency exchange operations are the major inspection area with legality as its basic criterion. This means verification whether the entrepreneur carries out currency exchange activity in compliance with the requirements specified in the Foreign Exchange Law and specific provisions. The scope of this verification is broad and includes also inspection by counting the content of the cash register. It also needs to be highlighted that currency exchange operators are obliged to submit statistical reports to the state's balance of payments and international investment position, which is why inspection of currency exchange operations may be also extended to include statistical reporting and then one can talk of comprehensive inspection.

The second area of NBP's inspection-related activity includes inspection of individual foreign exchange licenses issued by the President

13 Ordinance of the Minister of Finance on equipping a premise allocated for operating a currency exchange office and the manner of keeping records and issuing proofs of purchase and sale of foreign exchange assets of September 24, 2004, Journal of Laws no. 219 item 2219 as amended.

14 Ustawa o przeciwdziałaniu praniu pieniędzy i finansowaniu terroryzmu [Act on preventing money laundering and financing of terrorism] of March 1, 2018, consolidated text Dz. U. of 2020 item 971 as amended. 
of the NBP. At present this inspection has marginal importance due to a decrease in the number of decisions issued in the discussed scope. This, in turn, is a consequence of liberalization of the foreign exchange law that happened gradually after Poland's accession to the EU ${ }^{15}$. The role of individual foreign exchange licenses decreased because many foreign exchange activities were allowed under the statute or by general authorization ${ }^{16}$. Inspection of individual foreign exchange licenses should involve investigating whether the use of the issued foreign exchange license proceeds in compliance with its terms. This takes the form of a strongly individualized inspection and has an ex post nature ${ }^{17}$. In the event of finding violations of the terms of the license, the President of the NBP may revoke a previously-issued license, though before issuing a revoking decision he is obliged to investigate the evidence. It also needs to be highlighted that in the case of inspection of individual foreign exchange licenses it may take the form of an initial inspection which occurs as part of a procedure preceding the issuance of a decision on granting an individual license. It is because the President of the NBP is obliged to determine each time whether the applicant meets the criteria and premises laid down in the Foreign Exchange Law ${ }^{18}$. It needs to be remembered that individual foreign exchange licenses play a special role as they mitigate the consequences of foreign exchange restrictions. In the Polish legislation, the Fiscal Criminal Code ${ }^{19}$ classifies in section 97 "extortion of a license" as a fiscal crime against foreign exchange, punishable by a fine or imprisonment, or by both of these punishments jointly. Activities performed on the basis of an extorted license must be considered as performed without a license $\mathrm{e}^{20}$.

15 Kowalewska, "Narodowy Bank Polski," 684.

16 Wanda Wójtowicz, "Kontrowersje wokół pojęcia obrotu dewizowego," in Ex iniuria non oritur ius. Ksiega ku czci Prof. Wojciecha Eączkowskiego, eds. Andrzej Gomułowicz and Jerzy Małecki (Poznań: Wydawnictwo Uniwersytetu im. Adama Mickiewicza, 2003), 42, 48.

17 Ewa Kowalewska, Kontrola dewizowa wykonywana przez Narodowy Bank Polski (Warsaw: CeDeWu, 2017), 156.

18 Zbigniew Ofiarski, Prawo dewizowe. Komentarz (Warsaw: Zakamycze, 2003), 5.

19 Fiscal Criminal Code Act of September 10, 1999, consolidated text Journal of Laws of 2020 item 19, section 97

20 Adam Bartosiewicz and Ryszard Kubacki, Kodeks karny skarbowy. Przestęstwa i wykroczenia podatkowe oraz dewizowe (Warsaw: C.H. Beck, 2010), 265-266. 
The third area of inspection involves the statistical reporting obligation. Providing information necessary for drawing up the state's balance of payments and international investment position is associated with responsibilities resulting from participation in the European System of Central Banks (ESCB) and the European Central Bank (ECB). These issues result from Protocol no. 4 on the status of the ESCB and the ECB which is an annex to the Treaty on the Functioning of the $\mathrm{EU}^{21}$ and ECB guidelines of 9 December 2011 on the statistical reporting requirements of the ECB in the field of external statistics ${ }^{22}$. On the national ground, the statistical reporting obligation results from section 23a of the Act on the National Bank of Poland which specifies the manner of providing information necessary to draw up a balance of payments and international investment position. This information is transmitted electronically using appropriate certificates issued by the NBP or other authentication forms applied by the bank. In turn, detailed data associated with providing the NBP with the information in question is regulated by the Regulation from the Minister of Development and Finance ${ }^{23}$ (2017) on providing the NBP with information necessary to draw up a balance of payments and international investment position. It specifies the procedure, scope and time limits for fulfilling the obligation to provide the information to the NBP as well as the amounts which when exceeded cause the emergence of this obligation. It needs to be highlighted that firstly this obligation concerns entities which actively participate in foreign exchange, and secondly, the acts of foreign exchange performed by them exceed the specified amounts as the threshold amounts. The legislator uses the term "reporting entity". It encompasses residents who perform acts under foreign exchange and currency exchange operators. The entities are specified by the acts they per-

21 Treaty on the Functioning of the European Union, OJ C 326, 26.10.2012, 47-390.

22 Guideline of the ECB of 9 December 2011 on the statistical reporting requirements of the ECB in the field of external statistics (recast) (ECB/2011/23), OJ L 65, 3.3.2012, 1.

23 Ordinance of the Minister of Development and Finance on providing the National Bank of Poland with information necessary for drawing up the balance of payments and international investment position of August 9, 2017, Journal of Laws of 2017 item 1548. 
form. The information is provided to the NBP on dedicated forms called statistical reports ${ }^{24}$.

\section{CENTRAL BANKING AND FOREIGN EXCHANGE INSPECTION IN THE CZECH REPUBLIC}

In the Czech Republic the Čská Národni Banka (CNB) is a state institution created after the division of Czechoslovakia on the basis of the Act on the Czech National Bank ${ }^{25}$. The CNB has regular functions of a central bank but it also supervises banks. It needs to be emphasized that as a result of numerous amendments, this act was adjusted to the requirements of EU law.

The supreme governing body of the CNB is the Bank Board consisting of seven members - the Governor, two Deputy Governors and four other members of the Bank Board. Pursuant to the Constitution of the Czech Republic $^{26}$ the CNB is the central bank of the state. Its primary purpose is to maintain price stability ${ }^{27}$. At the same time, is has been shown that the central bank should support the government's economic policy (focused on long-term growth) as long as it does not jeopardize the primary purpose $^{28}$. As demonstrated above, the aim of the CNB's activity overlaps with the NBP's purpose.

The CNB's main tasks include conducting internal and external foreign currency policy, issuing banknotes and coins, inspection of the amount of money on the market, management of foreign exchange reserve in gold and foreign currency, granting credit and maintaining bank accounts ${ }^{29}$. The CNB's monetary policy strategy, similar to the NBP, focuses on the in-

24 Kowalewska, "Kontrola dewizowa," 166.

25 Act on the Czech National Bank of December 17, 1992, 6/1993 Sb. (Collection of Law) as amended.

26 Constitution of the Czech Republic of December 16, 1992, 1/1993 Sb. (Collection of Law), section 98.

27 Remigiusz W. Kaszubski and Marcin Krysa, "Prawne gwarancje niezależności banków centralnych w Polsce, Czechach i na Węgrzech,” Glosa, no. 5 (2002): 10, 15.

28 Violetta Kałuzińska, Przejrzystość polityki pieniężnej (Warsaw: CeDeWu, 2013), 110.

29 Kałuzińska, Przejrzystość, 110. 
flation objective. The exchange-rate policy is based on the principle of the floating exchange rate of the Czech koruna in relation to other currencies. The Czech Republic, like Poland, remains outside the Euro zone. This is why there is still special emphasis in legislation placed on the principle of operation of the internal foreign exchange market.

In compliance with the Act on the Czech National Bank, the central bank is an authority performing financial market supervision. It establishes rules of protection of stability of the banking sector, the capital market, the insurance industry and pension funds. It systematically supervises observance of regulations and if necessary imposes penalties for non-compliance.

Moreover, it needs to be pointed out that the CNB is responsible for carrying out inspections of entities engaged in trading in national currency in the form of coins and banknotes. This inspection involves:

a) issuing decisions in terms of licenses, permits and registration applications,

b) verifying compliance of regulations and direct application of regulations of the EU law,

c) application of remedies and penalties under the law,

d) conducting proceedings for administrative offences (specified in the Foreign Exchange Act).

The Foreign exchange law in the Czech Republic, like in Poland, has specific features and methods of regulation. The state monopoly in terms of foreign exchange, even in Czechoslovakia, was a result of a statutory regulation introduced in 1953 as Foreign Exchange Law. Introduction of a limitation on accepting payment in foreign currencies by natural persons and on taking national currency abroad is considered to mark the beginning of foreign exchange restrictions ${ }^{30}$. The Czech literature points to the fact that the Polish act of October 1950 on holding foreign currency, gold coins, gold and platinum and making punishments for foreign exchange offences more severe greatly impacted all foreign exchange regulations in the countries of Eastern Europe, mainly by introducing sanctions. These countries' membership in the Council for Mutual Economic

30 Petr Mrkyvka, Determinace a diverzifikace financniho prava (Brno: Masarykova univerzita, 2012), 192. 
Assistance had significant impact on the convergence of foreign exchange regulations of these countries ${ }^{31}$.

In line with the provisions of the 1995 Czech Foreign Exchange Act, the entities competent in foreign exchange matters are the Ministry of Finance and the CNB. Under the statute, the Ministry of Finance within its activity exercises inspection over organizational units, local government units, state funds and towards all persons in terms of loans granted or taken by the Czech Republic. The CNB exercises inspection in terms of its activity towards residents and non-residents. In the scope of foreign currency trading the CNB's responsibilities also include foreign exchange reserve management, which is regulated in the Act on the Czech National Bank ${ }^{32}$.

Foreign currency bodies as part of their responsibilities inspect the observance of the provisions of the Foreign Exchange Act and to this end may require the inspected entities to cooperate, inter alia by submitting all explanations and necessary documents ${ }^{33}$. These entities are obliged under the statute to provide all necessary information during the inspection. A foreign exchange inspection of a currency exchange office is mainly based on documents and explanations from persons who are responsible for running it. The inspection comes as a follow-up.

In the event of violation of the provisions of the Foreign Exchange Act the organ competent for the inspection may:

a) recommend that all shortcomings be remedied and deficiencies repaired; it sets a suitable deadline for it (the inspected entity is obliged to inform about the way the irregularities are to be removed),

b) suspend the activity which is contrary to the provisions of the Foreign Exchange Act (the competent organ for foreign exchange matters specifies the time and scope of suspension),

c) prohibit activity contrary to the statute,

d) remove an entity from the register or revoke a special permit,

e) impose a financial penalty.

31 Mrkyvka, Determinace, 192.

32 Věra Hartlová, Marcela Soldánová, Jitka Svobodová and Michaela Zlebková, Bankovnictvǐ. Pro středni školy a veřejnost (Prague: Fortuna, 2004), 137.

33 Milan Bakeš, Marie Karfiková, Peter Kotáb and Hana Marková, Finančni právo (Prague: C.H. Beck, 2012), 384-385. 
An entity in which violations of the law were found and which was recommended to remove the indicated shortcomings is obliged to inform the foreign exchange inspection body about how the shortcomings shall be remedied within the time limit specified by the foreign exchange inspection body. If a decision to suspend the activity is made, the foreign exchange inspection body specifies the time and scope of the suspension.

The Czech Foreign Exchange Act, unlike the Polish one, specifies the essence of administrative offences of a foreign currency nature. They are strictly associated with responsibilities the legislator imposed on residents and non-residents. It may be assumed that an offence occurs when a resident or non-resident has violated their statutory obligations or performs them in an inadequate manner. The legislator provides that a legal or natural person who operates a foreign exchange activity without registration or contrary to it commits an offence. Moreover, failure to fulfil statistical reporting duties by a resident or non-resident who carries out activity in the country is also an offense. When a resident or non-resident does not produce an appropriate foreign exchange permit or if he does not specify the purpose of payments coming from abroad it is also classified as an offence. Pursuant to the provisions of the Czech foreign exchange law residents and non-residents are obliged, when summoned, to specify the purpose of a payment coming from abroad where this purpose has not been previously listed.

An original measure in the Czech Foreign Exchange Act involves specifying the amount of fines for individual foreign exchange offences. The legislator specified the limits of these fines in three different places in the statute. Each time the amount of the fine depends on the type of violation. Fines' limits range from CZK 20,000,000 to CZK 100,000.

Moreover, the Foreign Exchange Act's characteristic feature involves defining when an administrative offence occurs. In this scope the following constitute an administrative offence:

a) operating currency exchange activity in a place different to the one specified in the register of the Czech National Bank,

b) the currency exchange operator's failure to inform about a change or liquidation of a place of carrying out the activity, 
c) the currency exchange operator's failure to provide specific information to the inspection bodies and handling information obtained as part of performing certain obligations,

d) failure to meet formal requirements specified for currency exchange activity.

Additionally, the legislator reserves that a legal person is not liable for an administrative offence if they have made every effort to ensure that the obligations are not breached. When determining the amount of a fine for a legal person the gravity of the offence and the manner it has been committed must be taken into account, as well as the consequences and circumstances of committing thereof. Legal persons' liability for an offence occurs when an administrative authority initiated proceedings within one year from the date it learnt about it but no later than 5 years from the date of occurrence of the offence. The CNB is the first instance for cases of administrative offences specified in the Foreign Exchange Act.

Czech foreign exchange legislation additionally specifies the so-called deposit duty. It should be imposed only in the case of unfavorable phenomena affecting the state's balance of payments, and also where excessive inflow of capital was observed, which brings the risk of widening of the capital imbalance which might lead to serious economic and financial dangers, including weakening the national currency, and which cannot be warded off effectively by means of traditional instruments of monetary policy.

Specification of the so-called state of emergency in the foreign exchange economy is a characteristic feature of instruments adopted on the ground of the foreign exchange law. It may occur in two situations. A state of emergency in the foreign exchange economy is declared by the government by announcing information in the media. A state of emergency primarily means a state when the ability to make payments to other countries is jeopardized, both directly and seriously. Moreover, this state occurs when the internal monetary balance of the Czech Republic is directly and seriously compromised.

In the time of a state of emergency, in a situation where the ability to make payments to other countries is jeopardized, the legislator forbids acquisition of foreign exchange assets in exchange for Czech currency and making any payments from the Czech Republic to other countries, in- 
cluding transfers of money between banks and their branch offices, and depositing funds on accounts abroad, unless a foreign exchange authority has granted a special permit. At a time of a state of emergency, when the internal monetary balance is jeopardized, it is forbidden to sell domestic securities, to accept financial credits from non-residents, to establish in the Czech Republic accounts for non-residents, to deposit money on accounts of non-residents, and to transfer money from another country to the Czech Republic between banks and their branch offices, unless a foreign exchange authority has granted a special permit.

The state of emergency in the foreign exchange economy is introduced on the date the government announces it and terminates on the date set by the government, but not later than three months from the date it was announced in the mass media.

\section{CENTRAL BANKING, FOREIGN EXCHANGE INSPECTION AND FINANCIAL SUPERVISION IN GERMANY}

The Federal Republic of Germany (Germany) is a "democratic and social federal state" (Basic Law for the Federal Republic of Germany) ${ }^{34}$, composed of 16 federated states. Germany is a state which actively participates in the processes of European integration and forms the monetary union along with other EU countries. In recent years, the German banking system has undergone a fundamental transformation ${ }^{35}$.

The German banking sector formed in the second half of the ninetieth century along with the emergence of first banks in the form of joint-stock companies. They are the oldest elements of German banking ${ }^{36}$. The twenty-first century is a time of essential transformations in German banking which resulted in changes in the international market (inter alia accelerated globalization process and technological progress) ${ }^{37}$.

34 Grundgesetz fur die Bundesrepublik Deutschland of May 23,1949, BGBl. S. 1.

35 Stanisław Flejterski and Jan K. Solarz, Systemy bankowe krajów G-20 (Szczecin: Zapol, 2012), 298.

36 Bernd Sprenger, "Das deutsche Bankwesen im Zeittalter der industralisierung," Bank, no. 10 (1987): 576-579.

37 Flejterski and Solarz, System, 302. 
The currently operating Deutsche Bundesbank (hereinafter Bundesbank) in Germany with its office in Frankfurt am Main was established by the Act on the German Federal Bank ${ }^{38}$. This started a new stage in the development of central banking in Germany and in the German banking system. The beginnings of the one-tier central banking system, independent of the federal government, are associated with this act. At present, the Bundesbank is a federal institution of public law that holds competence rights of a German federal state body. This amendment introduced changes in the structure of managing the bank. Elements of a two-tier structure of German banking were removed and the Executive Board is the only body managing the German Federal Bank ${ }^{39}$.

The Bundesbank, being a member of the ESCB, participates in shaping and implementing the monetary policy of countries belonging to the Euro zone. It is a participant of a decision-making process and contributes to decisions made by the ECB. Moreover, the Bundesbank enforces the ECB's decisions which concern issuing Euro banknotes in Germany and carries out the ECB's credit operations with German commercial banks ${ }^{40}$.

The Bundesbank at the same time fulfils all regular functions of a central bank, that is an issuing bank, a banks' bank and a central bank of the State. What is more, as in Poland and the Czech Republic, it safeguards the foreign exchange reserve. It organizes the issuance of German government securities, carries out state's payments and manages Germany's foreign reserve funds, where major foreign currency operations require the ECB's approval ${ }^{41}$. The Bundesbank's internal structure and organization are tailored to its responsibilities and functions.

The state's significant role in the development and shaping of activity in the entire banking sector in Germany is reflected in the tradition

38 Gesetz über die Deutsche Bundesbank of July 26, 1957, BGBI. I S. 745.

39 Władysław Baka, Bankowość centralna. Funkcje-metody-organizacja (Warsaw: Wydawnictwo Zarządzenie i Finanse, 2001), 158.

40 Eugeniusz Gostomski, Bankowość międzynarodowa (Gdańsk: Wydawnictwo Uniwersytetu Gdańskiego, 2011), 156.

41 Tomasz Ciszak, Anna Górska, Bartosz Otachel, Małgorzata Siemaszko, Renata Żak and Marcin Żogała, “Europejski System Banków Centralnych,” 2004, http://www.nbp.pl/ publikacje/esbc/esbc.pdf, p. 25. 
of the banking regulation and supervision system ${ }^{42}$. The literature points mainly to the evolution of the banking supervision process. On the basis of the act in force in Germany, in terms of supervision the Bundesbank is co-responsible for exercising it together with the supervisory authority. Bilateral agreement is the basis for this cooperation.

The Bundesbank's main responsibilities include cooperation in terms of issuing Euro banknotes and coins, issues concerning the financial and monetary system, supervision over banks, organization of cash and noncash transactions, as well as settling transactions in securities. On request of the federal government, the central bank draws up the statistics of Germany's balance of payments and international investment position. Moreover, it prepares analyses and conducts research activity on the financial system, mainly its stability.

Referring to the issue of foreign exchange inspection (in particular inspection of currency exchange offices) one needs to note that relevant significant changes occurred in the German legal system in 1998. Before this date the Act on Preventing Money Laundering was in force (its 2008 version is in force at the moment). Authorities competent for inspection, with regard to the economic activity, do not have appropriate authorization in terms of obtaining information and verifying reports. Inspection was mainly carried out in terms of observance of regulations specifying procedures preventing money laundering. However, tools of efficient foreign exchange inspection of currency exchange operators proved insufficient.

It needs to be emphasized that significant changes in terms of the functioning of the German inspection system, for which Germany's central bank is responsible, were introduced by the Act Establishing the Federal Financial Supervisory Authority ${ }^{43}$. The newly-established office, BaFin in short, took over all functions performed previously by the Federal Banking Supervisory Office, the Federal Insurance Supervisory Office and the Federal Securities Supervisory Office.

42 Lesław Góral, Nadzór bankowy (Warsaw: Polskie Towarzystwo Ekonomiczne, 1998), 102.

43 Gesetz über die Bundesanstalt für Finanzdienstleistungsaufsicht (Finanzdienstleistungsaufsichtsgesetz - FinDAG) of April 22, 2002, BGBl. I S. 1310. 
The Federal Financial Supervisory Authority - BaFin, similar to the supervisory office functioning in Poland (Financial Supervisory Authority [Komisja Nadzoru Finansowego, KNF]) is an authority of integrated supervision over the entire financial market. Integration of supervision over institutions functioning on the financial market is in line with contemporary European trends. Nevertheless, it seems that BaFin's competences cover a more broadly defined financial market. This results from the fact that the activity of financial institutions (including currency exchange offices) was regulated in a different way in German legislation.

The German supervision authority - BaFin safeguards the stability and solvency of banks, investment funds of insurance companies and protects interests of customers and investors ${ }^{44}$. The legislation in force obliges BaFin to work closely with the Bundesbank, primarily in terms of conducting current supervision over all institutions performing banking and foreign exchange operations, mainly through inspecting the observance of laws, guidelines and regulations. It is done by verifying reports and "on-site" inspections.

An important element of collaboration between the Bundesbank and BaFin involves respecting a certain principle stating that provisions of the law issued by BaFin and other banking regulations affecting behavior of banks and other operators are required to be agreed with the Bundesbank. On the other hand, the Bundesbank is obliged to inform BaFin on an ongoing basis about its decisions and more important facts that take place in the operation of, inter alia, banks ${ }^{45}$.

The Foreign Trade and Payments Act ${ }^{46}$ regulates issues concerning inspection carried out by the German Federal Bank. Pursuant to its provisions the Bundesbank has exclusive competence in terms of movements of capital and payments and the movement of foreign assets and gold. Regulations of the following acts are significant for foreign exchange inspection: the Bundesbank Act ${ }^{47}$ and the Banking Act ${ }^{48}$. Given the adopt-

44 Thomas Hartmann-Wendels, Andreas Pfingsten and Martin Weber, Bankbetriebslehre (Berlin: Springer, 2007), 46.

45 Baka, Bankowość, 162.

46 Ausenwirtschaftsgesettz of June 6, 2013, BGBI. I S. 1482.

47 Gesetz über die Deutsche Bundesbank In der Fassung der Bekanntmachung of October 22, 1992, BGBI. I S. 1782; amended BGBI. I S. 1981.

48 Gesetz über das Kreditwesen - KWG of September 9, 1998, BGBl. I S. 2776. 
ed measures, it is noticeable that foreign currency trading in German credit institutions is a financial service and requires a permit pursuant to the Banking Act ${ }^{49}$.

Moreover, the Banking Act introduced the requirement of obtaining a permit. It is required for dealing in foreign notes and coins and selling and buying travelers' cheques. In accordance with laws in force foreign exchange offices are institutions providing financial services, permits for the operation of which are issued by BaFin (the sixth amendment to the Banking Act, which entered into force on 1 January 1998 specified the socalled financial services carried out under a license). In line with the Banking Act, whoever intends to carry out (provide) financial services gainfully, as well as in the scope for which it is necessary to have a registered office, needs BaFin's permission for the opening and carrying out an activity of a financial nature.

The above shows that the rules for obtaining a currency exchange operator's license are regulated in Germany in a different way than in Poland and the Czech Republic. In Germany the crucial assumption is that currency exchange offices are institutions providing financial services with all related consequences. Therefore, the supervisory authority issues the relevant permission. Poland and the Czech Republic granted currency exchange offices a special status according to which the power to issue permits for operating such an activity is held by the organ of the central bank.

According to the provisions of the Banking Act, financial services include inter alia foreign currency dealing ("das Sortengestchaft"). The term "Sortenhandel" means exchange of banknotes or coins which are legal tender and selling and buying travelers' cheques. The term "sorten" which occurs in German legislation covers the exchange of national legal tender for foreign legal tender and buying and selling travelers' cheques. It is strictly necessary for financial institutions involving "sorten" to have a permit. Undertakings for whom dealing in banknotes and coins does not constitute their principal activity are treated differently from the point of view of supervision. Hotels and travel offices are given as an example $\mathrm{e}^{51}$.

49 Section 1(1a) sentence 2, point 7 of the Banking Act.

50 Section 1(1a) sentence 2, point 7 of the Banking Act.

51 Section 2(6) sentence 1, point 12 of the Banking Act. 
Ongoing inspection carried out by the Bundesbank also consists in monitoring quarterly reports. Detailed rules in this regard are stipulated by the Regulation on Financial Information Reporting ${ }^{52}$. Undertakings providing financial services involving foreign currency dealing are required to provide information that should include the following content elements: name of the undertaking, its head office, the reporting period, quantities and amounts of transactions broken down by currency and size (up to EUR 2,500; between EUR 2,500 and EUR 15,000, over EUR 15,000). The data contained in the said information include banknotes and coins which are foreign legal tender as well as travelers' cheques made out in a foreign currency.

In terms of such financial services BaFin and the Bundesbank work closely together, within the limits specified by the law ${ }^{53}$. The cooperation in question involves inter alia the Bundesbank's ongoing supervision over such financial institutions. However, taking into consideration the content of the Banking Act ${ }^{54}$, the Bundesbank must observe BaFin's guidelines. This means that the central bank in Germany has the right to inspect currency exchange if this inspection should proceed as part of guidelines issued by BaFin.

The cooperation of BaFin and the Bundesbank, whose framework is expressly specified by German legislation, means strict division of competences in terms of the discussed foreign exchange inspection of currency exchange offices. In most general terms: BaFin issues permits, while the Bundesbank carries out ongoing foreign exchange inspection.

The legislator clearly showed which elements of content a permit application must include. When issuing permits, BaFin may include terms and conditions in them. The supervisory authority publishes decisions in cases for granting a permit in the Federal Gazette. Moreover, it is obliged to maintain a register of financial institutions to which permits have been issued pursuant to the statute, along with the date of issuance thereof and the scope of application (or possibly the date of expiry of a permit or its

52 Verordnung zur Einreichung von Finanzinformationenverordnung - Fina V of December 6, 2013.

53 Section 7(1) Banking Act.

54 Section 7(2) Banking Act. 
suspension). It seems that the register referred to in German legislation, maintained by BaFin, from the point of view of formal requirements is similar to the register of currency exchange offices which in the Polish legal system must be kept by the President of the NBP.

The above reflections point out that in Germany organizational matters are vested in an institution other than the central bank. Moreover, the Federal Minister of Finance may issue detailed rules concerning the content of the register by resolution which does not require consent from the Upper House of the Parliament. If a financial activity requires having a location, the provisions of the German Code of Administrative Procedure ${ }^{55}$ will additionally apply.

However, it needs to be emphasized that the Bundesbank carries out ongoing supervision which includes in particular:

- analysis of the documentation submitted by financial institutions, audit reports and financial statements as well as documents concerning the balance sheets,

- an analysis of banking reports in order to assess institutions' capital adequacy and risk management procedures of these institutions.

\section{CONCLUSIONS}

The above discussion presents an analysis of legal instruments of an important issue within the competence of the central bank, namely foreign exchange inspection. An important assumption which outlined the direction of this analysis involved the fact that the three represented legal systems have a different origin and despite standardizing principles on the ground of the EU the visible differences between them result from different political and economic experiences. The limits of research are specified by regulations addressing the central bank, foreign exchange inspection and the functioning of supervision, in each of the three analyzed domestic legislations. Without a doubt, Poland and the Czech Republic have corresponding instruments in the investigated scope, which include

55 Verwaltungsgerichtsordnung (VwGO) of March 19, 1991, BGBl. I S. 686. 
the activity of the central bank, while Germany has developed a system based on cooperation of a few institutions.

The legislation in force in Poland and the Czech Republic in an extensive and detailed manner establishes norms regulating the basis of carrying out foreign exchange inspection, its scope, time limits and related obligations. One may feel that the Czech Foreign Exchange Act goes even a step further since it penalizes foreign exchange offences and introduces detailed regulations not prescribed for by the Polish legislator. Therefore, it might be concluded that the Czech Foreign Exchange Act is comprehensive but at the same time creates a rather rigid and restrictive system. The content of the regulations adopted in these countries does not raise doubt in such matters as the personal and material scope of foreign exchange inspection. It needs to be noted that exclusive powers in this scope were attributed to the central bank's authorities. A special feedback was forged in this way. The central bank introduces foreign exchange inspection within the limits in which it itself granted permission or maintains the register of currency exchange offices. A certain linking of powers has occurred. In Poland and in the Czech Republic currency exchange operations are the major areas of foreign exchange inspection. It needs to be noted that contrary to German arrangements, such activity is not an element of a broadly understood financial market within the limits specified by binding legislation. One cannot conclude that a currency exchange office is a financial institution or another similar institution. Supervisory regulations covering the financial market will not be applicable in this case. In terms of foreign exchange inspection in Germany the central bank became tied with the supervision authority. Thus cooperation of two important institutions occurs. At the same time this entails certain consequences primarily in the fact that currency exchange offices in Germany are institutions under the supervision of the supervision authority (BaFin).

Only the area of inspection that involves reporting was focused at the central bank in each of the adopted legal constructs.

This results primarily from the fact that on the European level, due to membership in the ESCB, domestic central banks were given the responsibility to gather data that is significant, for example the state's balance of payments and international investment position. 
The differences resulting from the investigation concern the fact that Poland and the Czech Republic are not in the Euro zone, while Germany is a country that has been part of the monetary union from the beginning. The second reason for the discrepancies, indicated above, involves a different past in the functioning of the central bank or the financial market, as well as different historical and economic contexts.

Referring to the hypothesis set forth in the methodology it needs to be highlighted that regulations on foreign exchange inspection should be verified at the EU level and despite significant Europeanization of the adopted legal instruments their standardization should be considered. It is also important due to the transnational activity in the business sphere and freedom of trading in foreign exchange.

The analysis carried out in this study shows that the matters of trading in foreign exchange and foreign exchange inspection fall under the competence of domestic legislation and it is difficult to talk about uniform (EU) rules at this moment. It also needs to be noted, that the ĆNB has the broadest competences among the above-presented domestic legislation, where the ĆNB, apart from performing regular functions of a central bank discussed above, is also a supervisory authority over the financial market and is an authority for compulsory restructuring and resolution. In Poland the KNF is the supervisory authority and the Bank Guarantee Fund is the compulsory restructuring authority. In turn in Germany, it is the Bundesbank and BaFin, respectively (principally in terms of cooperation).

\section{REFERENCES}

Aufricht, Hans. Comparative Survey of Central Bank Law. New York, Washington: Frederick A. Praeger, 1965.

Baka, Władysław. Bankowość centralna. Funkcje-metody-organizacja. Warsaw: Wydawnictwo Zarządzenie i Finanse, 2001.

Bakeš, Milan, Marie Karfiková, Peter Kotáb, and Hana Marková. Finančni právo. Prague: C.H. Beck, 2012.

Baltyn, Paweł. "Modelowe ujęcie polityki monetarnej w warunkach kryzysu." In Wspótczesny system bankowy. Ujęcie interdyscyplinarne, edited by Joanna Świderska, 264-320. Warsaw: Difin, 2013. 
Bartosiewicz, Adam, and Ryszard Kubacki. Kodeks karny skarbowy. Przestępstwa i wykroczenia podatkowe oraz dewizowe. Warsaw: C.H. Beck, 2010.

Ciszak, Tomasz, Anna Górska, Bartosz Otachel, Małgorzata Siemaszko, Renata Żak, and Marcin Żogała. "Europejski System Banków Centralnych.” (2004): 1-54. http://www.nbp.pl/publikacje/esbc/esbc.pdf.

Flejterski, Stanisław, and Jan K. Solarz. Systemy bankowe krajów G-20. Szczecin: Zapol, 2012.

Fojcik-Mastalska, Eugenia. "Miejsce i rola prawa walutowo - dewizowego w systemie prawa." In Prawo finansowe w warunkach cztonkostwa Polski w Unii Europejskiej. Księga Jubileuszowa dedykowana Profesor Wandzie Wójtowicz, edited by Alicja Pomorska, Paweł Smoleń, and Jarzy Stelmasiak, 99-107. Lublin: Wydawnictwo Uniwersytetu Mari Curie-Skłodowskiej, 2011.

Gostomski, Eugeniusz. Bankowośc międzynarodowa. Gdańsk: Wydawnictwo Uniwersytetu Gdańskiego, 2011.

Gronkiewicz - Waltz, Hanna. Bank centralny od gospodarki planowej do rynkowej. Warsaw: Wydawnictwo Prawnicze, 1992.

Góral, Lesław. Nadzór bankowy. Warsaw: Polskie Towarzystwo Ekonomiczne, 1998.

Hartlová, Věra, Marcela Soldánová, Jitka Svobodová, and Michaela Zlebková. Bankovnictvǐ. Pro středni školy a veřejnost. Prague: Fortuna, 2004.

Hartmann-Wendels, Thomas, Andreas Pfingsten, and Martin Weber. Bankbetriebslehre. Berlin: Springer, 2007.

Kałuzińska, Violetta. Przejrzystość polityki pieniężnej. Warsaw: CeDeWu, 2013.

Kaszubski, Remigiusz W., and Marcin Krysa. "Prawne gwarancje niezależności banków centralnych w Polsce, Czechach i na Węgrzech." Glosa, no. 5 (2002): $10-15$.

Kowalewska, Ewa. "Narodowy Bank Polski jako centralna bankowa instytucja dewizowa." Finanse, Rynki Finansowe, Ubezpieczenia, no. 79 (2016): 679-686.

Kowalewska, Ewa. Kontrola dewizowa wykonywana przez Narodowy Bank Polski. Warsaw: CeDeWu, 2017.

Kowalewska, Ewa. "Ustawodawstwo dewizowe w systemie prawa - analiza z perspektywy członkostwa Polski w Unii Europejskiej." In Obywatel - Państwo - Spoteczność Międzynarodowa, edited by Ewelina Cała - Wacinkiewicz, Kinga Flaga - Gieruszyńska, and Daniel Wacinkiewicz, 570-585. Warsaw: C.H. Beck, 2014.

Mrkyvka, Peter. Determinace a diverzifikace financniho prava. Brno: Masarykova univerzita, 2012. 
Mroczkowski, Rafał. "Status prawny, cele, funkcje i zadania Narodowego Banku Polskiego." In Podstawy finansów i prawa finansowego, edited by Andrzej Drwiłło, 351-359. Warsaw: Wolters Kluwer, 2018.

Ofiarski, Zbigniew. Prawo dewizowe. Komentarz. Warsaw: Zakamycze, 2003.

Oplustil, Krzysztof, and Marek Porzycki. "Unia walutowa w Europie." In Instytucje gospodarki rynkowej, edited by Tadeusz Włudyka, and Marcin Smaga. Warsaw: Wolters Kluwer, 2018.

Owsiak, Stanisław. "Bank centralny.” In Bankowość, edited by Małgorzata Zaleska, 13-35. Warsaw: C.H. Beck, 2013.

Sprenger, Bernd. "Das deutsche Bankwesen im Zeittalter der industralisierung." Bank, no. 10 (1987): 576-579.

Wójtowicz, Wanda. "Kontrowersje wokół pojęcia obrotu dewizowego." In Ex iniuria non oritur ius. Ksiega ku czci Prof. Wojciecha Eaczkowskiego, edited by Andrzej Gomułowicz, and Jerzy Małecki, 39-48. Poznań: Wydawnictwo Uniwersytetu im. Adama Mickiewicza, 2003. 